\title{
Time for New Recommendation of Upper Limit of Serum Vitamin D in Humans
}

\author{
Peter Schwarz, Prof., MD, DMSc ${ }^{1,2 *}$ \\ ${ }^{1}$ Department of Endocrinology, Diabetes and Bone-metabolic Research Unit Rigshospitalet, Copenhagen, Denmark \\ ${ }^{2}$ Faculty of Health Sciences, University of Copenhagen, Denmark
}

${ }^{*}$ Corresponding author: Peter Schwarz, Professor, MD, DMSci. Department of Endocrinology, Rigshospitalet Blegdamsvej 9, 2100 København Ø, Denmark; Office: 3545 7574; Cell: 5239 4595; Email: peter.schwarz@regionh.dk

Received: July 30, 2019; Accepted: August 13, 2019; Published: September 27, 2019;

\begin{abstract}
There is a continued debate and exchange of knowledge with respect to serum 25- hydroxyvitamin D (25(OH)D) cut-off levels. Based on our current knowledge it is time to reconsider our recommendations of the optimal level of serum $25(\mathrm{OH}) \mathrm{D}$ in the clinical setting and not only focus on low levels but also recommend an upper serum limit of around $125 \mathrm{nmol} / \mathrm{L}(40-50 \mathrm{ng} / \mathrm{mL})$ among healthy and diseased.
\end{abstract}

Keywords: Vitamin D

\section{Issues and Opinions}

There is a continued debate and exchange of knowledge with respect to serum 25-hydroxyvitamin $\mathrm{D}(25(\mathrm{OH}) \mathrm{D})$ cut-off in the lower end and when to start supplementation. This debate includes the general population as well as in a long list of diseases. The discussion of a cut-off level insufficiency and deficiency of $25 \mathrm{mmol} / \mathrm{L}(10 \mathrm{ng} / \mathrm{mL})$ and $50 \mathrm{mmol} / \mathrm{L}(20 \mathrm{ng} / \mathrm{mL})$, respectively, is one debate another is the optimal level of serum 25(OH)D and of most importance a missing debate of a recommended upper limit.

It is well known that vitamin D plays an essential role in the regulation of metabolism, calcium and phosphorus absorption. Essentially, the effect of vitamin D is in the hydroxylated form 1,25-dihydroxy vitamin D. However, the effects of vitamin D are not limited to mineral homeostasis and skeletal health maintenance. The presence of Vitamin D Receptors (VDR) in other tissue and organs suggest that vitamin $\mathrm{D}$ physiology extends well above and beyond bone homeostasis in cell and animal studies. There has been an association of serum 25(OH)D deficiency to several diseases among others osteoporosis, cancers, autoimmune disorders, infectious diseases, cardiovascular disease, Type 2 Diabetes (T2D) and neurological disorders such as sclerosis [1]. Knowledge from the literature is that low levels are problematic and strong associations are published indicating higher morbidity and mortality among individuals with the low levels of serum $25(\mathrm{OH}) \mathrm{D}<50 \mathrm{mmol} / \mathrm{L}(20 \mathrm{ng} / \mathrm{mL})$. On the other hand, clinical randomized studies do not so far support the beneficial effect of vitamin D supplementation other than in osteoporosis, falls and fractures.

A vitamin D dose range of 20-25 $\mu$ g (800-1000 IU) per day has been effective in several studies whereas lower doses have generally been ineffective. Further hereto several doses above this range have increased the risk of falls and therefor the recommendation is that older adults with serum $25(\mathrm{OH}) \mathrm{D}$ levels $<40 \mathrm{nmol} / \mathrm{L}$ likely have fewer falls if supplemented with $20-25 \mu \mathrm{g}(800-1000 \mathrm{IU})$ per day of vitamin $\mathrm{D}$ [2]. A recent RCT showed maximum decrease in falls at 12-month serum $25(\mathrm{OH}) \mathrm{D}$ level of $80-95 \mathrm{nmol} / \mathrm{L}(32-38 \mathrm{ng} / \mathrm{mL})$ and of extreme importance is that the faller rates increase when the serum $25(\mathrm{OH}) \mathrm{D}$ level exceed $40-45 \mathrm{ng} / \mathrm{mL}(100-112.5 \mathrm{nmol} / \mathrm{L})$ [3].

We have learned from clinical randomized studies (RCT) with high-dose vitamin D supplementation that for mental health benefit is seen when normalizing. But no benefit is seen of higher high levels of monthly doses of vitamin D compared with the standard monthly dose of $600 \mu \mathrm{g}$ (24,000 IU) [4]. Monthly high-dose vitamin D supplementation does not prevent Cardio-Vascular Disease (CVD) [5] and a combined study evaluating supplementation with vitamin Ddid not show a lower incidence of cardiovascular events or invasive cancer than placebo [6]. Long-term vitamin Dsupplementation, which increased mean 25-hydroxyvitamin D3 concentration $>100 \mathrm{nmol} / \mathrm{L}$ for 18 months, had no effect on systolic or diastolic BP in predominantly white, healthy adults without severe vitamin D deficiency [7].In a long-time the authors of a RCT showed no significant lung function improvements in a study of high-dose vitamin D versus placebo [8]. It is often claimed that vitamin $\mathrm{D}$ might protect colo-rectal cancer but among patients with metastatic colo-rectal cancer, addition of high-dose vitamin $\mathrm{D}_{3}$ vs standard-dose of vitamin $\mathrm{D}_{3}$ to standard chemotherapy was inconclusive indicating the need of further and larger multicenter randomized clinical trials [9]. Related hereto, patients with digestive tract cancer, vitamin D supplementation, compared with placebo, did not result in significant improvement in relapse-free survival at 5 years [10]. Looking at neurology, the latest published meta-analysis of vitamin D supplementation in sclerosis were including all the RCT's and highlighted the very low-quality of these and the missing evidence of effect as data suggests no benefit of vitamin $\mathrm{D}$ for patient-important outcomes among people with 
multiple sclerosis (MS). Several studies inMS is initiated and will likely provide further evidence that can be included in a future updates [11]. A meta-analysis of 19 RCT's of vitamin D supplementation in T2D patients shows that supplementation seem to improve HbAlc, insulin resistance, and insulin in short-term intervention, suggesting that vitamin $\mathrm{D}$ can be considered as a therapeutic agent along with the other treatments for T2D if patients are supplemented at low serum levels [12]. In patients with pre-diabetes and hypovitaminosis D, high dose vitamin $\mathrm{D}$ improves insulin sensitivity and decreases risk of progression toward diabetes [13]. In thyroid disease no significant changes were observed in the serum levels of $\mathrm{T} 3$ and $\mathrm{T} 4$ hormones to vitamin D supplementation and therefore further well controlled, large, longitudinal studies are needed [14]. In all these executed studies the included patients mostly improve serum 25(OH)D from low to normal levels and in few cases to high levels and as presented the risk of fall increases.

Several epidemiologic studies support a serum 25(OH)D upper limit of $100-125 \mathrm{nmol} / \mathrm{L}(40-50 \mathrm{ng} / \mathrm{mL})$ when evaluating all-cause mortality [15,16], CVD [17] and cancer [18]. The J-shaped curve indicate significant higher risk than benefits at levels higher than $100-125 \mathrm{nmol} / \mathrm{L}(40-50 \mathrm{ng} / \mathrm{mL})$ and the above mentioned high-dose RCT's does not report on benefits.

In the literature the excess and toxicity levels of serum $25(\mathrm{OH}) \mathrm{D}$ are as high as $250 \mathrm{nmol} / \mathrm{L}(100 \mathrm{ng} / \mathrm{mL})$ and $325 \mathrm{nmol} / \mathrm{L}(150 \mathrm{ng} / \mathrm{mL})$, respectively. Based on the literature we have no evidence in support of a normal level up to $250 \mathrm{nmol} / \mathrm{L}(100 \mathrm{ng} / \mathrm{mL})$.

I think it is time to reconsider our recommendations of the optimal level of serum 25(OH)D in the clinical setting and not only focus onlow levels but also recommend an upper serum limit of around 125 $\mathrm{nmol} / \mathrm{L}$ (40-50 ng/mL) among healthy and diseased (Table 1).

Table 1. Diagnostic clinical cut-offs of levels of serum 25(OH)D

\begin{tabular}{|c|c|c|}
\hline $\begin{array}{c}\text { Serum 25(OH) Level } \\
(\mathbf{n m o l} / \mathbf{L})\end{array}$ & $\begin{array}{c}\text { Serum 25(OH) Level } \\
(\mathbf{n g} / \mathbf{m L})\end{array}$ & $\begin{array}{c}\text { Laboratory } \\
\text { Diagnosis }\end{array}$ \\
\hline$<25$ & $<10$ & Insufficiency \\
\hline$<50$ & 25 & Deficiency \\
\hline $50-125$ & $25-50$ & Normal \\
\hline$>125$ & $>50$ & Excess \\
\hline$>325$ & $>150$ & Intoxication \\
\hline
\end{tabular}

\section{References}

1. Holick MF (2017) The vitamin D deficiency pandemic: Approaches for diagnosis, treatment and prevention. Rev Endocr Metab Disord 18: 153-165.

2. Dawson-Hughes B (2017). Vitamin D and muscle function. J Steroid Biochem Mol Biol 173: 313-316.

3. Smith LM, Gallagher JC, Suiter C (2017). Medium doses of daily vitamin D decrease falls and higher doses of daily vitamin D3 increase falls: A randomized clinical trial. J Steroid Biochem Mol Biol 173: 317-322.

4. Gugger A, Marzel A, Orav EJ, Willett WC, Dawson-Hughes B et al (2019) Effect of Monthly High-Dose Vitamin D on Mental Health in Older Adults: Secondary Analysis of a RCT. J Am Geriatr Soc..

5. Scragg R, Stewart AW, Waayer D, Lawes CMM, Toop L, et al (2017) Jr. Effect of Monthly High-Dose Vitamin D Supplementation on Cardiovascular Disease in the Vitamin D Assessment Study : A Randomized Clinical Trial. JAMA Cardiol 2: 608-616.

6. Manson JE, Cook NR, Lee IM, Christen W, Bassuk SS, et al (2019) Vitamin D Supplements and Prevention of Cancer and Cardiovascular Disease. N Engl J Med 380: 33-44.

7. Scragg R, Slow S, Stewart AW, Jennings LC, Chambers ST, et al (2014) Longterm high-dose vitamin D3 supplementation and blood pressure in healthy adults: a randomized controlled trial. Hypertension 64: 725-730.

8. Sluyter JD, Camargo CA, Waayer D, Lawes CMM, Toop L, et al (2017) Effect of Monthly, High-Dose, Long-Term Vitamin D on Lung Function: A Randomized Controlled Trial. Nutrients 9(12).

9. Ng K, Nimeiri HS, McCleary NJ, Abrams TA, Yurgelun MB, et al (2019) Effect of High-Dose vs Standard-Dose Vitamin D3 Supplementation on Progression-Free Survival Among Patients With Advanced or Metastatic Colorectal Cancer: The SUNSHINE Randomized Clinical Trial. JAMA 321: 1370-1379.

10. Urashima M, Ohdaira H, Akutsu T, Okada S, Yoshida M, et al (2019). Effect of Vitamin D Supplementation on Relapse-Free Survival Among Patients With Digestive Tract Cancers: The AMATERASU Randomized Clinical Trial. JAMA 321: 1361-1369.

11. Jagannath VA, Filippini G, Di Pietrantonj C, Asokan GV, Robak EW, et al (2018). Vitamin D for the management of multiple sclerosis. Cochrane Database Syst Rev 9: CD008422.

12. Hu Z, Chen J, Sun X, Wang L, Wang A(2019) Efficacy of vitamin D supplementation on glycemic control in type 2 diabetes patients: A meta-analysis of interventional studies. Medicine (Baltimore) 98: e14970.

13. Niroomand M, Fotouhi A, Irannejad N, Hosseinpanah F (2019). Does high-dose vitamin D supplementation impact insulin resistance and risk of development of diabetes in patients with pre-diabetes? A double-blind randomized clinical trial. Diabetes Res Clin Pract 148: 1-9.

14. Chahardoli R, Saboor-Yaraghi AA, Amouzegar A, Khalili D, Vakili AZ, et al (2019) Can Supplementation with Vitamin D Modify Thyroid Autoantibodies (Anti-TPO $\mathrm{Ab}$, Anti-Tg Ab) and Thyroid Profile (T3, T4, TSH) in Hashimoto's Thyroiditis? A Double Blind, Randomized Clinical Trial. Horm Metab Res 51: 296-301.

15. Durup D, Jorgensen HL, Christensen J, Schwarz P, Heegaard AM, et al (2012). A reverse J-shaped association of all-cause mortality with serum 25-hydroxyvitamin D in general practice: the CopD study. J Clin Endocrinol Metab 97: 2644-2652.

16. Sempos CT, Durazo-Arvizu RA, Dawson-Hughes B, Yetley EA, Looker AC, et al (2013). Is there a reverse J-shaped association between 25-hydroxyvitamin D and all-cause mortality? Results from the U.S. nationally representative NHANES. $J$ Clin Endocrinol Metab 98: 3001-3009.

17. Durup D, Jorgensen HL, Christensen J, Tjonneland A, Olsen A, et al (2015). A Reverse J-Shaped Association Between Serum 25-Hydroxyvitamin D and Cardiovascular Disease Mortality: The CopD Study. J Clin Endocrinol Metab 100: 2339-2346.

18. Vojdeman FJ, Madsen CM, Frederiksen K, Durup D, Olsen A, et al (2019). Vitamin D levels and cancer incidence in 217,244 individuals from primary health care in Denmark. Int $J$ Cancer 145: 338-346.

\section{Citation:}

Peter Schwarz (2019) Time for New Recommendation of Upper Limit of Serum Vitamin D in Humans. Endocrinol Diabetes Metab $J$ Volume 3(5): 1-2. 